\title{
Molecular recognition by artificial receptors
}

\author{
Willem Verboom, Dmitry M. Rudkevich, and David N. Reinhoudt* \\ Laboratory of Organic Chemistry, University of Twente, P.O. Box 217, 7500 AE \\ Enschede, The Netherlands
}

\begin{abstract}
Biological and synthetic receptors for three different types of guest species have been compared: valinomycin and calix [4]crown ethers for $\mathrm{K}^{+}$, urease and metallomacrocycles for urea, and phosphate binding proteins and synthetic anion receptors for different anions. The symbiosis of synthetic and biological receptors is demonstrated for transesterification reactions of amino acid esters by $\alpha$-chymotrypsin in organic solvents in the presence of crown ethers.
\end{abstract}

\section{Introduction}

The mimicry of natural recognition processes is one of the challenging research topics of supramolecular chemistry. Biological receptors consist of large linear molecules that form three dimensional structures by specific intramolecular interactions. The recognition sites offer a precise stereochemistry and exhibit very efficient recognition processes. However, this is achieved at the expense of a high molecular weight. A possible strategy for synthetic receptors comprises combination of medium-sized organic building blocks to which functional groups for molecular recognition can be attached. In this paper we present our recent results on the synthesis and evaluation of artificial receptors for the complexation of potassium cations, neutral molecules, and anions. In addition an example will be shown of the effect of crown ethers on enzymatic reactions in organic solvents.

\section{Complexation of potassium cations}

The natural antibiotic valinomycin is highly specific for the complexation of potassium cations. As a synthetic ionophore we developed the dialkoxycalix[4]arene crown ethers 1,2 . Previously, we reported that 1,3-dimethoxycalix[4]arene crown-5 1 shows a surprisingly high $\mathrm{K}^{+} / \overline{\mathrm{N}} \mathrm{a}^{+}$selectivity in extraction experiments (ref. 1). The preferred conformation for binding in 1 appeared to be flattened partial cone, where one of the methyl groups is located inside the apolar cavity of the calix[4]arene and the other near the polyether ring. ${ }^{1} \mathbf{H}$ NMR studies revealed that the flexible 1 undergoes a conformational reorganization from cone to partial cone upon complexation. Calix[4]arene crown-5 1 has been used as potassium-selective carrier in supported liquid membranes. Because of its high hydrophobicity stable fluxes were obtained. The transport selectivity for $\mathrm{K}^{+} / \mathrm{Na}^{+}$cations (Fig. 1) in competition experiments is as follows: valinomycin $>1>$ dibenzo-18-crown-6 (ref. 2). In order to investigate whether the complexing properties of 1 could be improved by reducing the conformational mobility, we prepared 1,3-diethoxycalix[4]arene crown-5 2 .

1,3-Dihydroxy-p-tert-butylcalix[4] arene crown-5 was dialkylated with ethyl iodide in THF/DMF in almost quantitative yield. Preparative thin layer chromatography $\left(\mathrm{Al}_{2} \mathrm{O}_{3}\right)$ of the crude mixture gave 2 as pure flattened cone (2a), partial cone (2b), and 1,3-alternate (2c) conformers in isolated yields of $53 \%$, $28 \%$, and $13 \%$, respectively (ref. 3 ). The binding free energies $\left(-\Delta \mathrm{G}^{\circ}\right)$ of the different conformers were determined by the two-phase (water/chloroform) picrate extraction method (Fig. 2). All ligands exhibit peak selectivity toward $\mathrm{K}^{+}$cations and as anticipated the partial cone stereoisomer (2b) shows the highest value of the association constant for all cations. The result clearly shows that in highly preorganized cation ligands such as $\underline{2}$, the stability of the complexes can be strongly affected by subtle changes in the geometry around the binding region. Recently, we found the same behavior of the $\mathrm{K}^{+} / \mathrm{Na}^{+}$selectivities based on chemically modified field effect transistor (CHEMFET) and membrane ion selective electrode (ISE) measurements (ref. 4). 


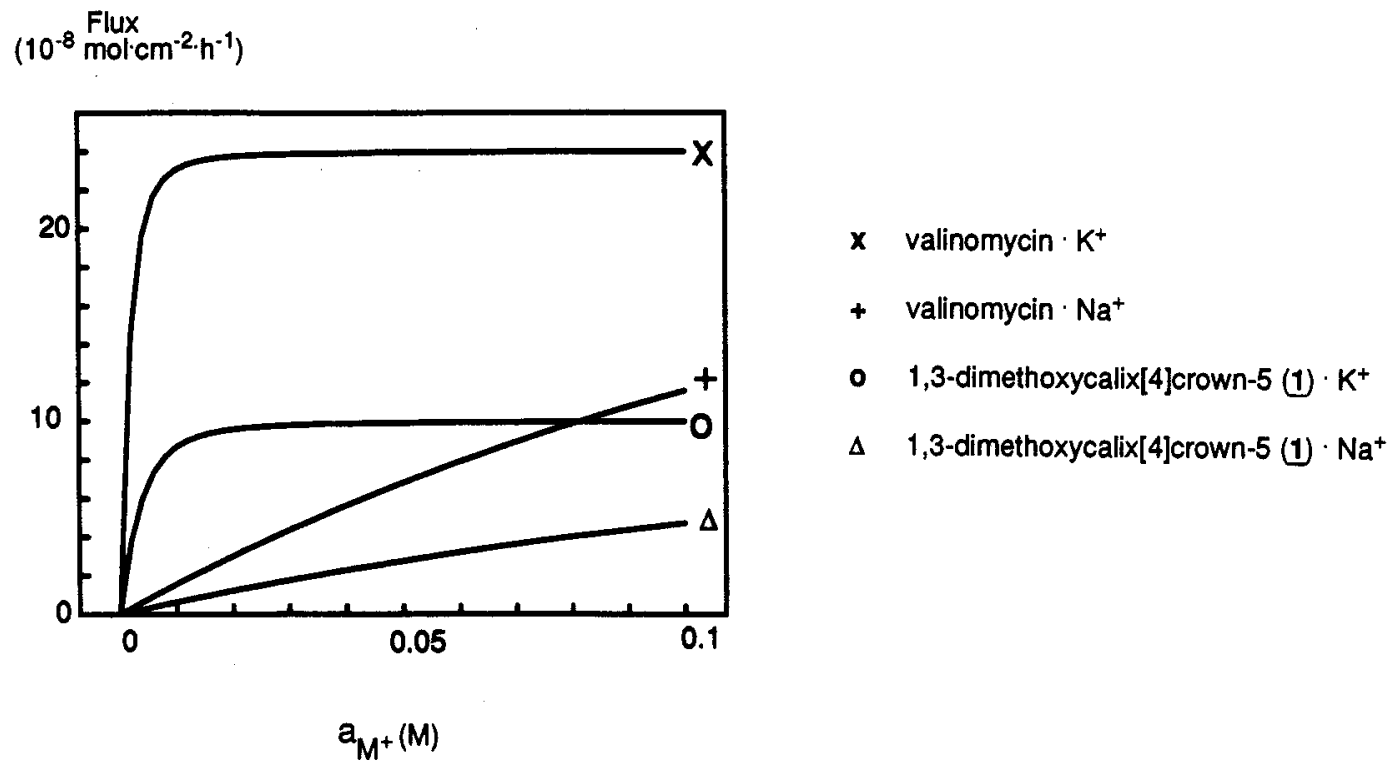

Fig. 1. Transport of $\mathrm{Na}^{+}$and $\mathrm{K}^{+}$by 1,3-dimethoxycalix[4]arene crown-5 $\underline{1}$

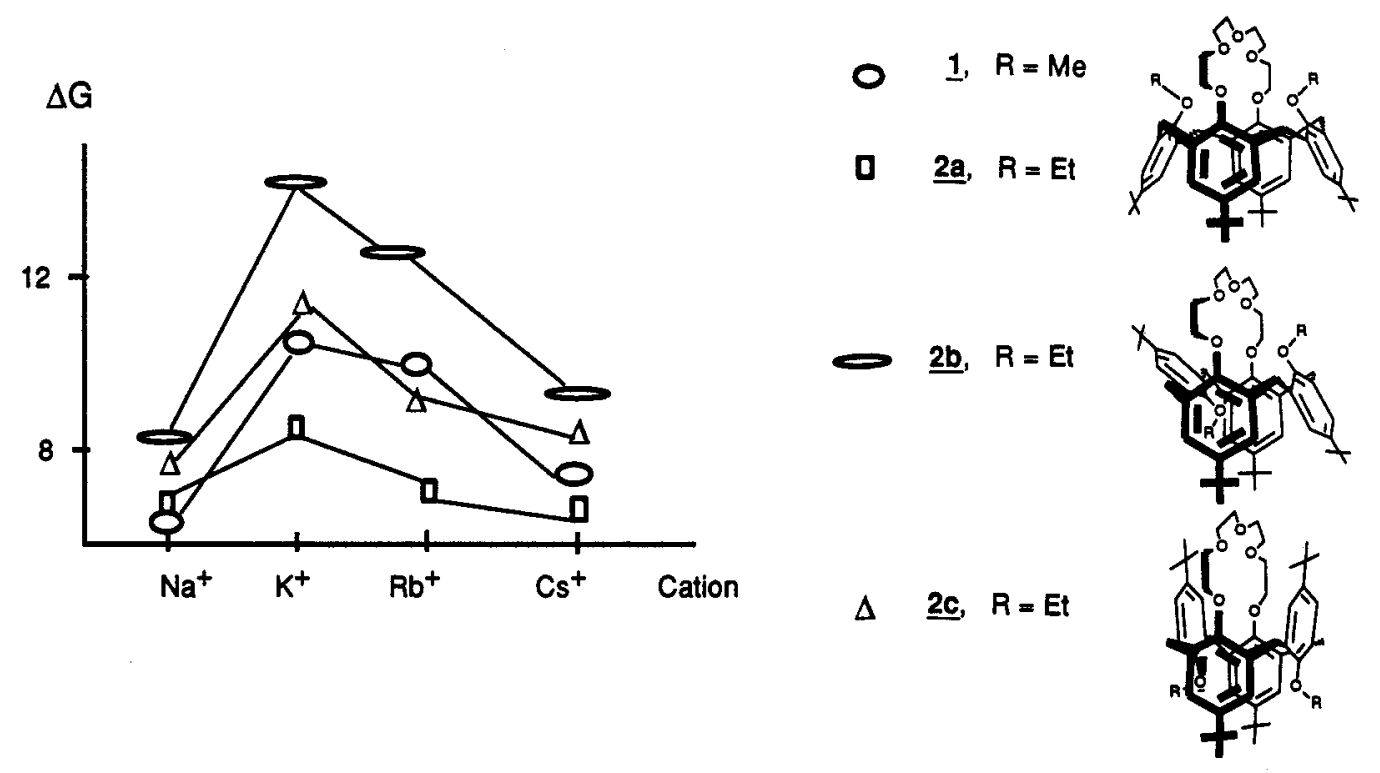

Fig. 2. Complexation properties of preorganized 1,3-dialkoxycalix[4]arene crown-5 derivatives $\underline{1}, \underline{2}$ 


\section{Complexation of neutral molecules}

The design and synthesis of receptors for neutral molecules has made substantial progress in the past decade (ref. 5). We developed a new approach on the basis of calix[4]arenes. According to our concept, the calix [4]arene is applied not for its cavity but as a platform on which a molecular cleft is constructed by selective functionalization. 1,3-Diaminocalix [4]arene $\underline{3}$ was reacted with 6-hydroxynicotinic acid (4) using carbonyl diimidazole as a coupling reagent to give the dipyridone calix [4]arene receptor 5 in $60 \%$ yield (ref. 6). This receptor is self-complementary and as a consequence oligomerization has been observed in $\mathrm{CDCl}_{3}$ according to vapor pressure osmometry and light scattering experiments. Addition of imidazolidone (a cyclic urea) disrupts the oligomers. Initially a 1:1 (5 imidazolidone) and at higher guest concentrations a 1:2 complex is formed. For the complexation of urea an association constant of $5.6 \times 10^{3} \mathrm{M}^{-1}$ was found on the assumption that a $1: 1$ complex is formed and that the degree of oligomerization of the uncomplexed host is not effected (Scheme 1).

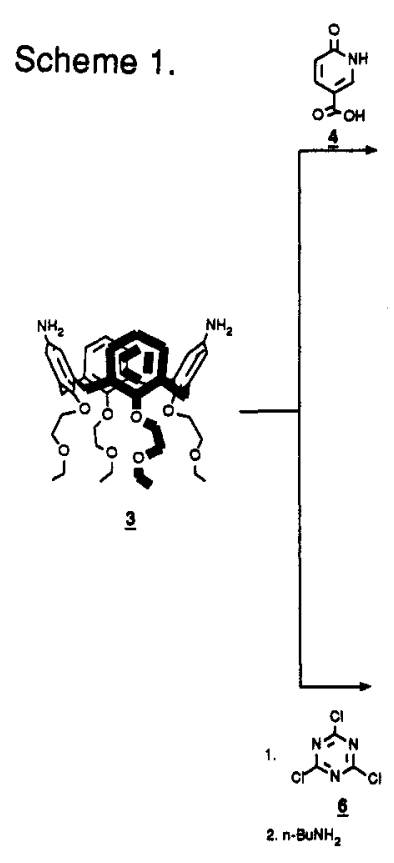

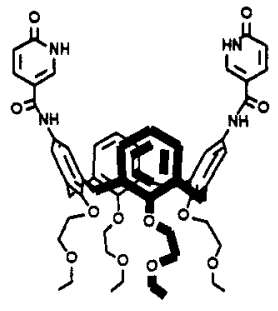

$\underline{\mathbf{s}}$



1

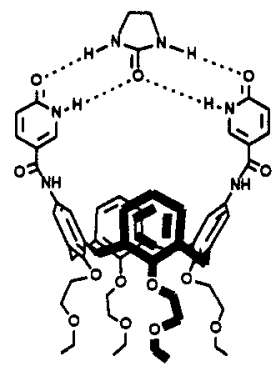

SImidazolidone

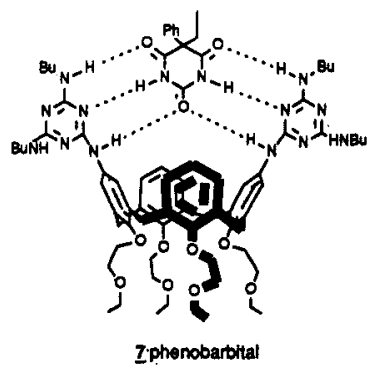

A recognition site shaped by two triazine units nas afforded a receptor with a H-bond array complementary to barbiturates. Receptor $\underline{7}$ was prepared by reaction of $\underline{3}$ with 2,4-dichloro-6-methoxy-1,3,5-triazine (6) in dioxane with $\mathrm{NaOH}$ as a base which resulted in the selective substitution of the chlorine atoms. The substitution of the second chlorine atom was accomplished by subsequent reaction with excess $n$-butylamine in refluxing dioxane to give receptor 7 in $40 \%$ overall yield (ref. 7) (Scheme 1). The butyl groups were introduced to increase the solubility of the receptor. Titration experiments in $\mathrm{CDCl}_{3}$ with phenobarbital [5-ethyl5-phenyl-2,4,6(1H,3H,5H)pyrimidinetrione] as a guest have revealed that both triazine units are involved in binding ( 7 . phenobarbital). The association constant $K$ is $520 \mathrm{M}^{-1}$ when the self-association of phenobarbital $\left(\mathrm{K}=8.5 \mathrm{M}^{-1}\right)$ is taken into account. Evidence has been obtained that upon complexation host $\underline{Z}$ is not symmetric, which is required for the formation of six $\mathrm{H}$-bonds.

For several years we have been interested in the design of specific receptors for urea (ref. 8). We found that 18-crown-6 and monoaza-18-crown-6 form very weak complexes with urea in a 1:5 stoichiometry (macrocycle : urea) (ref. 9). We were able to increase the stability of this type of complexes by protonation of the guest by an external acid or by assistance of an intra-annular acidic group (refs. $10,11)$. However, the drawback of Brönsted acidic groups is a limited pH range. We have realized that a proton is only one example of an electrophile. Initially, the complexation of a small electrophilic metal cation and urea in 2,6-pyridocrown ethers has been studied (ref. 12). In this case a drawback is that more than two species are needed in the complexation step. In order to overcome these problems we have developed a new generation of host molecules in which an immobilized Lewis acidic group instead of a proton is used as an electrophilic center. The Lewis acidic uranyl cation complexed in a salen or salophene unit prefers a pentagonal-bipyramidal coordination with the two oxygens in the apical positions and with the four coordination sites of the ligand and a neutral molecule in the equatorial positions. Based on this concept different types of uranyl containing metallomacrocycles and metalloclefts have been prepared. 
Metallomacrocycles 9 were synthesized by reaction of aldehydes $\underline{8}$ with cis-1,2-cyclohexanediamine in the presence of $\mathrm{Ba}^{2+}$ as a template cation and subsequent transmetallation with $\mathrm{UO}_{2}{ }^{2+}$ as depicted in Scheme 2 (ref. 13).

Scheme 2.

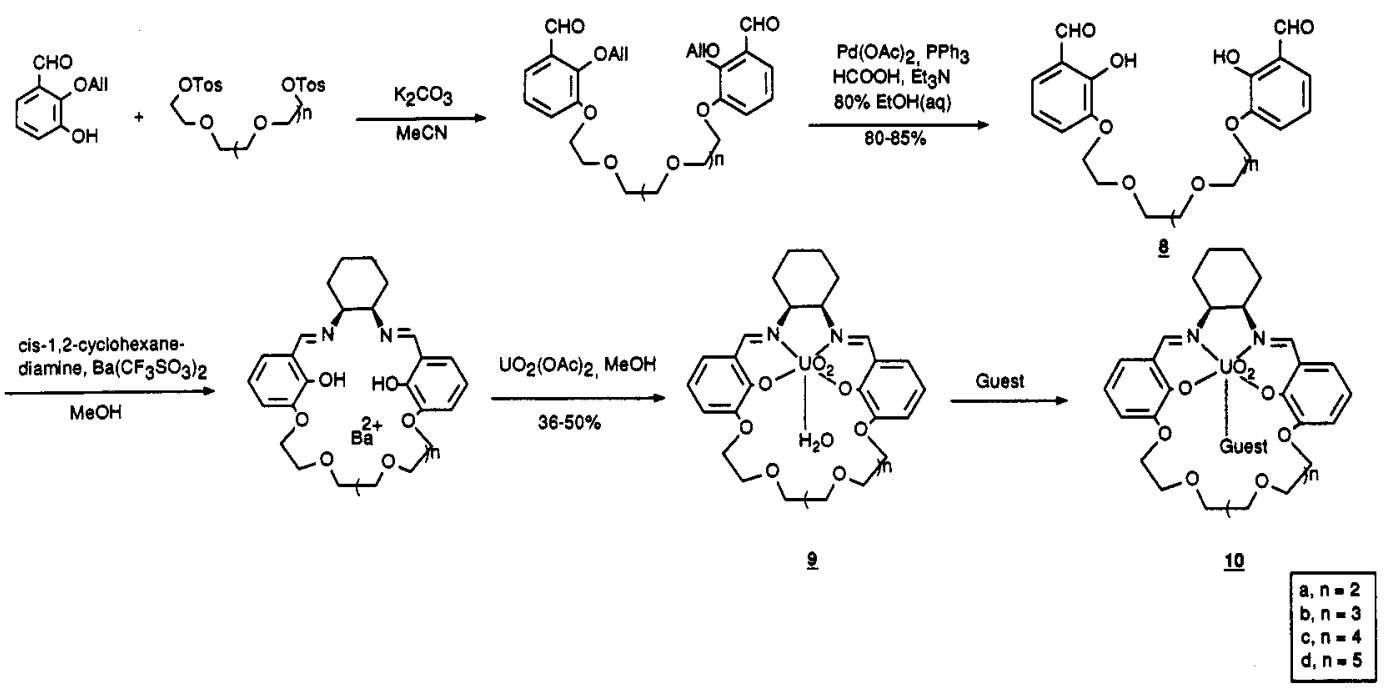

The complexation with neutral molecules was investigated by polarography, ${ }^{1} \mathrm{H}$ NMR spectroscopy, solid-liquid and liquid-liquid extraction experiments, X-ray structure determinations, and $a b$ initio calculations. Several solid complexes 10 of metallomacrocycles $9 \mathrm{~b}-\mathrm{d}$ with polar neutral molecules (formamide, acetamide, $N$-methylurea, hydroxyurea, urea, and DMSO) could be isolated. Polarography demonstrated a ring size dependence with the following stability order for the complexes in acetonitrile: urea $>N$-methylurea $>$ acetamide $\sim$ formamide $>$ acetone. The stability constant for the $10 \mathrm{~b} \cdot$ urea and $\underline{10 \mathrm{c}}$. urea complexes in $\mathrm{CDCl}_{3}$ are according to ${ }^{1} \mathrm{H}$ NMR spectroscopy at least $10^{8} \mathrm{M}^{-1}$; the highest number ever achieved by a complex consisting of a neutral metalloreceptor and a neutral molecule. The crystal structures of $10 \mathrm{~b}$. urea and $10 \mathrm{~d}$ ' urea complexes reveal that urea is encapsulated in the cavity and that the complexes are stabilized by coordination of the carbonyl oxygen of urea to the immobilized uranyl cation, multiple $\mathrm{H}$-bond formation, and electrostatic interaction between urea nitrogens and ether oxygens. $A b$ initio calculations suggest that charge transfer determines the coordination between the uranyl cation and urea. The optimal coordination angle $\left(\mathrm{C}=\mathrm{O} \cdots \mathrm{UO}_{2}{ }^{2+}\right)$ is approximately $130^{\circ}$, for both in-plane and perpendicular coordination. Metalloreceptors $9 \mathrm{~b}-\mathrm{d}$ transport urea through a supported liquid membrane by encapsulation of the guest in the molecular cavity. The ring size of the macrocycle has a large effect on the rate of transport (refs. 14,15).

In order to develop this type of macrocycles for use as potential model for the enzyme urease, we decided to replace one of the ethylene glycol units by a building block, which will allow the introduction of functional groups close to the cavity of the crown ether ring. For this purpose the binaphthyl unit was selected because it is known from the work of Cram et al. (ref. 16) on binaphthyl-18-crown-6 that substituents in the 3-and 3'-positions of the binaphthyl unit are just above and below the plane of the crown ether. The binaphthyl metallomacrocycles 12 were prepared by a $\mathrm{Ba}^{2+}$ templated cyclization of appropriately substituted dialdehydes 11 (prepared in a multistep synthesis from binaphthol) with either 1,2-benzenediamine or cis-1,2-cyclohexanediamine and subsequent transmetallation with $\mathrm{UO}_{2}{ }^{2+}$ (refs. 17,18). The complexing ability of $12 \mathrm{a}, \mathrm{b}$ was demonstrated by the isolation of solid urea complexes. In case of $12 \mathrm{c}, \mathrm{e}(\mathrm{n}=1)$ intramolecular complexation of the amide group was shown by ${ }^{1} \mathrm{H}$ NMR and IR spectroscopy and by cyclic voltammetry. For $12 \mathrm{c}(n=1)$ the intramolecular amide complex and the water complex could even be separated by flash column chromatography (ref. 18). The two different complexes were observed to interconvert slowly. However, the intramolecular complexation does not prevent the receptors from complexing urea. Unfortunately, no catalytic activity was observed for $12 \mathrm{~d}(\mathrm{n}=1)$ in the hydrolysis of urea in dioxane/water (4:1) at elevated temperatures (ref. 18). Binaphthyl metallomacrocycles $12 \mathrm{a}$ considerably increase the flux of urea through a supported liquid membrane compared with the blank flux. These carriers are hydrophobic enough to give stable membranes, in contrast to metallomacrocycles 9 which gave lower urea fluxes after each replacement due to partition of $\underline{9}$ to the aqueous phase (ref. 15). 

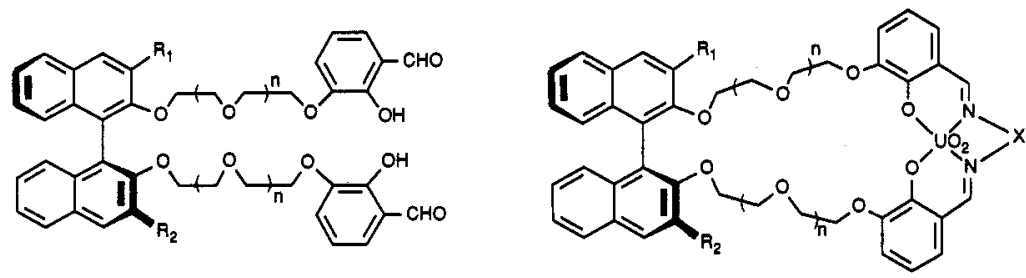

$n=1,2$

II

a $R_{1}=R_{2}=H$

b $R_{1}=H_{1} R_{2}=$

$c R_{1}=R_{2}=$<smiles>Cc1ccc(O)c(NC(=O)O)c1</smiles>

$n=1,2$

$\underline{12}$

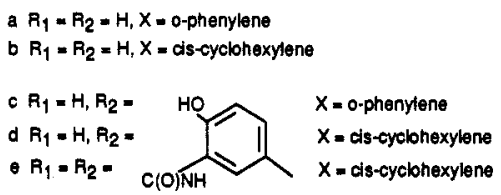

The additionally functionalized metallomacrocycle $\underline{13}$ combines a salen uranyl and a 2,6-diamidopyridine unit connected with a flexible spacer and appears to be a reasonable barbiturate receptor (ref.19). In $\mathrm{CDCl}_{3}$ solution 13 shows self-complexation which can be attributed to a triple point interaction between the uranyl and the 2,6-diamidopyridine moiety. The stability of the barbiturate complexes in solution is due to steric reasons strongly dependent on the substituents at the 5 -position of the barbiturate.

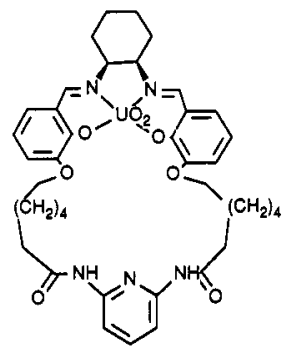

13

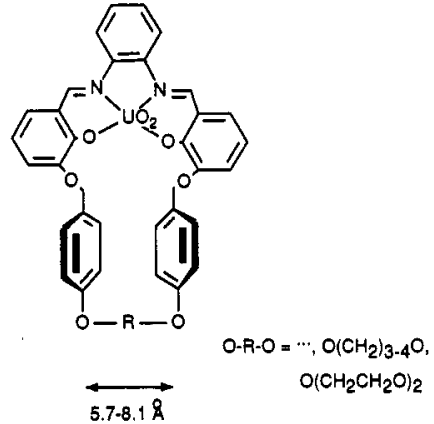

14

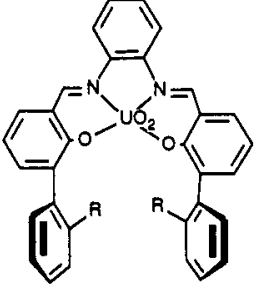

$R=H_{1} \mathrm{OMe}_{\mathrm{e}}$

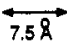

15

The salophene unit has also been applied as a building block for the metalloclefts $\underline{14}$ and $\underline{15}$ (ref. 20). Parallel orientation of the incorporated aromatic rings affords a cleft with aromatic walls and a Lewis acidic center positioned inside. ${ }^{1} \mathrm{H}$ NMR titration experiments and the crystal structure of the complex between 4-tert-butylpyridine and biphenyl cleft $15(\mathrm{R}=\mathrm{OMe})$ indicate that the neutral guests coordinate with their Lewis basic site at the uranyl, and that $\pi-\pi$ stacking of the aromatic rings of host and guest stabilizes the complexes. The stabilities of the complexes in solution have been determined by electrochemical methods. The metalloclefts show affinity for a variety of aromatic neutral molecules such as pyridines, pyridine- $N$-oxide, isoquinoline, and benzylamine. In the pyridine series there is a correlation between the basicity of the pyridine and the stability of the complex, when steric effects are absent. Steric repulsion between the methyl groups of 2,6-dimethylpyridine and the oxygen atom of the uranyl cation reduces the stability of the complexes significantly. In complexes with the biphenyl metalloclefts 15 stacking contributes $\leq 1.6 \mathrm{kcal}^{\prime} \mathrm{mol}^{-1}$ to the total energy of binding. In complexes with the benzyl cleft 14 , these values range from $1.7 \mathrm{kcal}^{\prime} \mathrm{mol}^{-1}$ for a flexible cleft (no spacer) to 2.2 $\mathrm{kcal} \cdot \mathrm{mol}^{-1}$ for a more preorganized metallocleft $\left(\right.$ spacer $\left.=\mathrm{O}\left(\mathrm{CH}_{2}\right)_{4} \mathrm{O}\right)$.

The larger cavity of binaphthyl metallocleft 16 should be an advantage in binding large aromatic molecules because the extended $\pi$ surface may increase the complex stabilities. Moreover, incorporation of a chiral binaphthyl unit offers the possibility to study the complexation properties of enantiomers. According to ${ }^{1} \mathrm{H}$ NMR spectroscopy 16 has been obtained as a mixture of meso and racemic diastereomers (ratio 1:0.85)(ref. 21). Basic aromatic guests like pyridine and (iso)quinoline give more stable complexes with meso-16 than with racemic-16. Preliminary experiments with chiral benzylmethylamine indicated the possibility of chiral recognition. 


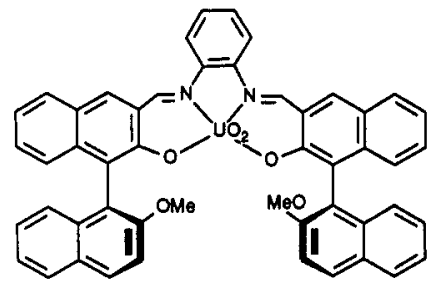

meso-16

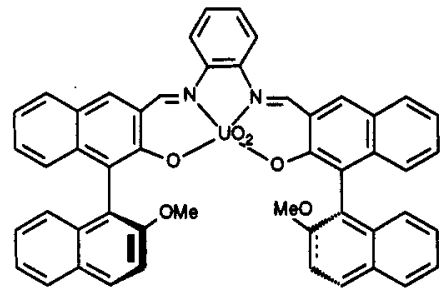

racernic-16

(one enantiomer shown)

\section{Complexation of anions}

In nature the selective ion flow from and to the cell is regulated by ion binding proteins which act as ion carriers and channels across the cell membrane. The selective biological recognition of phosphate by a transport receptor protein has recently been described (ref. 22). In our attempt to mimic nature in the recognition of anions by multiple three-dimensional hydrogen bond formation, we have designed a new series of neutral ligands. This strategy was based on the known structures of phosphate binding sites of proteins. The host molecules 17-24 were synthesized starting from diethylenetriamine and tris(aminoethyl)amine, respectively, by reaction with the appropriate acid chlorides in the presence of $\mathrm{Et}_{3} \mathrm{~N}$ as base in $70-90 \%$ isolated yield (ref. 23). The association constants for the complexation of ligands 17-24 with different anions using tetrabutylammonium as the counterion were determined in $\mathrm{MeCN}$ by conductometry and are given in Table 1 . These host molecules show selective binding affinity towards anions exclusively through $\mathrm{H}$-bonding. Although the association constants are not as high as those of the natural proteins, the simple molecular structure of the models offers the possibility for synthetic manipulation.<smiles>[2H]C(=O)N(CCNC(=O)P)CCNC(=P)P</smiles>

$17 \mathrm{R}=\mathrm{CH}_{2} \mathrm{Cl}$
$18 \mathrm{R}=\left(\mathrm{CH}_{2}\right)_{4} \mathrm{CH}_{3}$<smiles>O=C(P)NCCN(CCNC(=O)P)CCNC(=P)P</smiles>

$\frac{\mathrm{R}}{20}-\mathrm{CH}_{2} \mathrm{Cl}$
$\frac{20}{\mathrm{R}}=\left(\mathrm{CH}_{2}\right)_{4} \mathrm{CH}_{3}$
$\underline{21}=\mathrm{CH}_{6} \mathrm{H}_{3}$
$\underline{22} \mathrm{R}=4-\mathrm{MeOC}_{6} \mathrm{H}_{4}$<smiles>[12H]S(=O)(=O)NCCN(CCNS(=O)(=O)P)CCNS(=O)(=O)P</smiles>

$\begin{aligned} 23 & =4-M_{\theta} C_{6} H_{4} \\ R & =2-n a p h t h y\end{aligned}$

So far we only used uranyl containing metallomacrocycles and clefts for the complexation of neutral molecules (vide supra). However, we realized that this type of compounds may also be very useful for the complexation of anions. The simple salophene $\underline{25}$ already complexes different anions very well (ref. 24). In order to obtain selective anion receptors we introduced substituents which contain amido groups to the salen moiety (compounds 26,27). The association constants determined with conductometry of the complexation of 25-27 with different anions have been schematically depicted in Fig. 3. Receptor 27 shows for $\mathrm{H}_{2} \mathrm{PO}_{4}^{-}$selectivities of $>10^{3}$ and $>10^{4}$ for $\mathrm{Cl}^{-}$and $\mathrm{HSO}_{4}^{-}, \mathrm{NO}_{2}^{-}$and $\mathrm{SCN}^{-}$, respectively. This type of neutral anion receptors is based on the unique combination of a Lewis acidic uranyl center and the presence of amide $\mathrm{NH}$ groups which can form a favorable $\mathrm{H}$-bond with a coordinated anion guest. 
Table 1. Association constants $\left(\mathrm{K}_{\text {ass }}, \mathrm{M}^{-1}\right)$ in $\mathrm{MeCN}$ from conductometry

\begin{tabular}{l|rrr}
\hline Ligand & $\mathrm{H}_{2} \mathrm{PO}_{4}{ }^{-}$ & $\mathrm{HSO}_{4}{ }^{-}$ & $\mathrm{Cl}^{-}$ \\
\hline $\mathbf{1 7}$ & 4700 & 36 & 96 \\
$\mathbf{1 8}$ & 870 & 65 & 63 \\
$\mathbf{1 9}$ & 6100 & 170 & 1740 \\
$\underline{\mathbf{2 0}}$ & 280 & 31 & 290 \\
$\mathbf{2 1}$ & 870 & 56 & 100 \\
$\mathbf{2 2}$ & 510 & 73 & 190 \\
$\mathbf{2 3}$ & 3500 & 79 & 540 \\
$\mathbf{2 4}$ & 14200 & 38 & 1600 \\
\hline
\end{tabular}

O 25

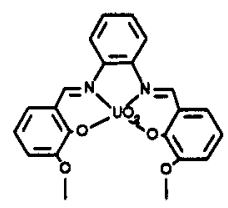

lgKass (MeCN-DMSO, 99:1)

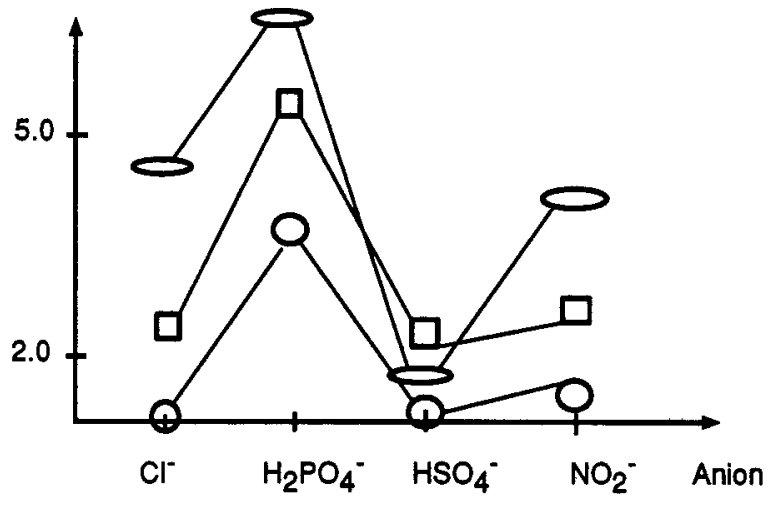

$\underline{26}$

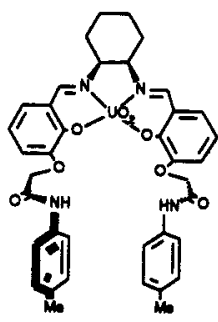

Fig. 3. Complexation of anions by $\mathrm{UO}_{2}$-salenes

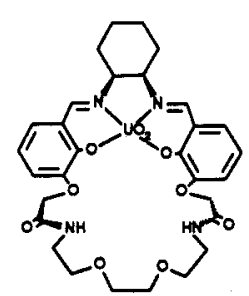

\section{Influence of crown ethers on enzyme-catalyzed reactions in organic solvents}

So far we have shown a number of examples of synthetic receptors with the ultimate objective the mimicry of natural recognition processes. However, we have found that crown ethers can also act as auxiliaries in enzymatic reactions in organic solvents having an accelerating effect on the reaction rate. In organic media enzymatic reactions proceed considerably slower than analogous reactions in aqueous solution. These reactions can be significantly enhanced by addition of crown ethers (ref. 25). For example crown ethers strongly enhance the transesterification of $N$-acetyl-l-phenylalanine ethyl ester with 1-propanol catalyzed by $\alpha$-chymotrypsin in various organic solvents. Of the different crown ethers tested, 18-crown-6 gave the best results. For the reaction in toluene using $2 \mathrm{mM} 18$-crown-6 an acceleration of about 20 times was observed. The influence of the 18-crown-6 concentration on the initial velocity of this reaction has been depicted in Fig. 4. The effect found is not simply due to an increased solubility of the enzyme in organic solvent. It has been shown that the increase of enzyme activity is due to a macrocyclic effect, i.e. open chain analogs of the crown ethers are not active. Largest activities are found for crown ethers which have a large affinity for water complexation and this effect is most pronounced in organic solvents of low polarity. 


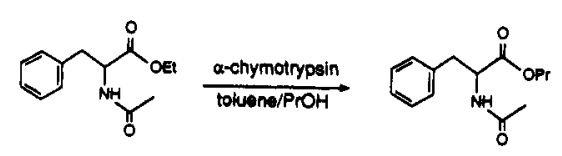

Conditions: $2.5 \mathrm{mM}$ ester, $1 \mathrm{MPrOH}$ in toluene, $0.5 \mathrm{mg}$ enzyme/ml (pretreated with potassium phosphate buffer), $25^{\circ} \mathrm{C}$.

Fig. 4. Influence of 18-crown-6 concentration on initial velocity

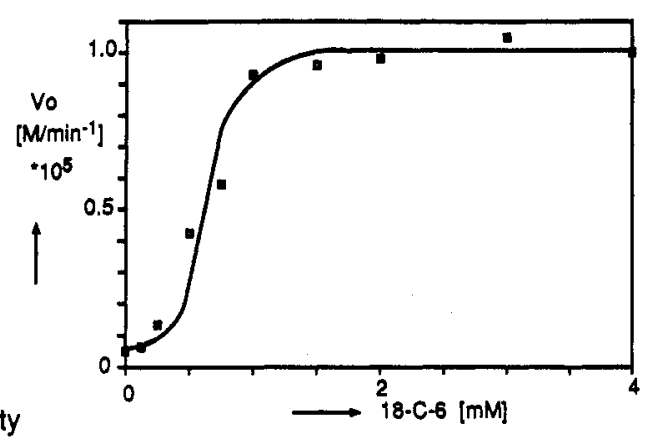

\section{References}

1. P.J. Dijkstra, J.A.J. Brunink, K.-E. Bugge, D.N. Reinhoudt, S.Harkema, R. Ungaro, F. Ugozzoli and E. Ghidini, J. Am. Chem. Soc. 111, 7567-7575 (1989).

2. W.F. Nijenhuis, E.G. Buitenhuis, F. de Jong, E.J.R. Sudhölter and D.N. Reinhoudt, J. Am. Chem. Soc. 113, 7963-7968 (1991).

3. E. Ghidini, F. Ugozzoli, R. Ungaro, S. Harkema, A. Abu El-Fadl and D.N. Reinhoudt, J. Am. Chem. Soc. $112,6979-6985$ (1990).

4. Z. Brzozka, B. Lammerink, E. Ghidini, R. Ungaro and D.N. Reinhoudt, J. Chem. Soc., Perkin Trans., in press.

5. A.R. van Doorn, W. Verboom and D.N. Reinhoudt, Advances in Supramolecular Chemistry, Vol. 3, JAI Press Inc., London, 159-206 (1993).

6. J.-D. van Loon, R.G. Janssen, W. Verboom and D.N. Reinhoudt, Tetrahedron Lett. 35, 5125-5128 (1992).

7. J.-D. van Loon, J.F. Heida, W. Verboom and D.N. Reinhoudt, Recl. Trav. Chim. Pays-Bas 111 , 353-359 (1992).

8. D.N. Reinhoudt, A.R. van Doorn and W. Verboom, J. Coord. Chem. 27, 91-104 (1992).

9. P.D.J. Grootenhuis, J. van Eerden, P.J. Dijkstra, S. Harkema and D.N. Reinhoudt, J. Am. Chem. Soc. $109,8044-8051$ (1987).

10. J.W.H.M. Uiterwijk, S. Harkema, D.N. Reinhoudt, K. Daasvath, H.J. den Hertog Jr. and J. Geevers, Angew. Chem. 94, 462-463 (1982).

11. C.J. van Staveren, V.M.L.J. Aarts, P.D.J. Grootenhuis, W.J.H. Droppers, J. van Eerden, S. Harkema and D.N. Reinhoudt, J. Am. Chem. Soc. 110, 8134-8144 (1988).

12. C.J. van Staveren, J. van Eerden, F.C.J.M. van Veggel, S. Harkema and D.N. Reinhoudt, J. Am. Chem. Soc. 110, 4994-5008 (1988).

13. A.R. van Doorn, R. Schaafstra, M. Bos, S. Harkema, J. van Eerden, W. Verboom and D.N. Reinhoudt, J. Org. Chem. 56, 6083-6094 (1991).

14. W.F. Nijenhuis, A.R. van Doorn, A.M. Reichwein, F. de Jong and D.N. Reinhoudt, J. Am. Chem. Soc. $113,3607-3608$ (1991).

15. W.F. van Straaten-Nijenhuis, A.R. van Doorn, A.M. Reichwein, F. de Jong and D.N. Reinhoudt, J. Org. Chem. 58, 2265-2271 (1993).

16. a. Y. Chao and D.J. Cram, J. Am. Chem. Soc. 98, 1015-1017 (1976).

b. Y. Chao, G.R. Weisman, G.D.Y. Sogah and D.J. Cram, J. Am. Chem. Soc. 101, 4948-4958 (1979).

17. A.M. Reichwein, W. Verboom and D.N. Reinhoudt, Recl. Trav. Chim. Pays-Bas, in press.

18. A.M. Reichwein, W. Verboom and D.N. Reinhoudt, submitted for publication.

19. A.R. van Doorn, D.J. Rushton, W.F. van Straaten-Nijenhuis, W. Verboom and D.N. Reinhoudt, Recl. Trav. Chim. Pays-Bas 111, 421-426 (1992).

20. A.R. van Doorn, M. Bos, S. Harkema, J, van Eerden, W. Verboom and D.N. Reinhoudt, J. Org. Chem. 56, 2371-2380 (1991).

21. A.R. van Doorn, D.J. Rushton, M. Bos, W. Verboom and D.N. Reinhoudt, Recl. Trav. Chim. Pays-Bas 111, 415-420 (1992).

22. H. Leucke and F.A. Quiocho. Nature, 347, 402-406 (1990).

23. S. Valiyaveettil, J.F.J. Engbersen, W. Verboom and D.N. Reinhoudt, Angew. Chem., in press.

24. D.M. Rudkevich, W.P.R.V. Stauthamer, J.F.J. Engbersen, S. Harkema, W. Verboom and D.N. Reinhoudt, J. Am. Chem. Soc. 114, 9671-9673 (1992).

25. J. Broos, M.-N. Martin, I. Rouwenhorst, W. Verboom and D.N. Reinhoudt, Recl. Trav. Chim. Pays-Bas $110,222-225$ (1991). 